\title{
Determination of Positioning Components in the Retail Market of Iran Market: A Mixed Methods Study
}

\author{
Shadi Hosseini ${ }^{1}$, Mira Seyed Abolghasem², Mohammad Rahim Esfidani², \\ Fereshteh Farzianpour $^{3 *}$ (D) \\ ${ }^{1}$ Marketing, University of Tehran, Alborz Campus, Iran \\ ${ }^{2}$ Faculty of Management, University of Tehran, Alborz Campus, Iran \\ ${ }^{3}$ Department of Health Management and Economics, School of Public Health, Tehran University of Medical Sciences, Tehran, \\ Iran \\ Email: Shadi_un@yahoo.com,smira@ut.ac.ir,esfidani@ut.ac.ir, *Farzianp@sina.tums.ac.ir
}

How to cite this paper: Hosseini, S., Abolghasem, M.S., Esfidani, M.R. and Farzianpour, F. (2019) Determination of Positioning Components in the Retail Market of Iran Market: A Mixed Methods Study. Journal of Service Science and Management, 12, 407-420.

https://doi.org/10.4236/jssm.2019.123028

Received: February 23, 2019

Accepted: April 14, 2019

Published: April 17, 2019

Copyright $\odot 2019$ by author(s) and Scientific Research Publishing Inc. This work is licensed under the Creative Commons Attribution International License (CC BY 4.0).

http://creativecommons.org/licenses/by/4.0/

\begin{abstract}
Positioning is a marketing concept that outlines what a business should do to market its product or service to its customers. In positioning, the marketing department creates an image for the product based on its intended audience. This is created through the use of promotion, price, place and product. The purpose of this research was to determine the condition of positioning components in the retail market of Iran market. This research was mixed methods (qualitative \& qualitative). For formulating the research theoretical model, by using academic sources, the papers, master and Ph.D thesis focusing on positioning of retail stores were considered in this section. In this regard, 16 domestic and 19 foreign studies were used as valid academic sources. Among 35 studies, only 25 studies were considered to provide benchmark table. In this research, data gathered through deep interviews with customers of selected public and private stores. Data analysis was done by using coding in MAXQDA software. Some quantitative data were analyzed by using SPSS. V.16 software. Demographic characteristics of participants were such that approximately $20 \%$ of participants had diploma and associate degree, $48 \%$ had B.A and $32 \%$ had M.A and Ph.D. About $71 \%$ of participants were lower than 30 years old, $69 \%$ were 31 - 50 years old. $62 \%$ were married. Generally, from among three obtained variables, commodity (203), store (198) and personnel (47) have the highest importance for Iran's retail store positioning, respectively.
\end{abstract}

\section{Keywords}

Positioning, Components, Retail Market, Iran 


\section{Introduction}

Positioning is a marketing concept that outlines what a business should do to market its product or service to its customers. In positioning, the marketing department creates an image for the product based on its intended audience. This is created through the use of promotion, price, place and product.

Retailing was one of the most dynamic industries during the last five years in Iran. Modern grocery channels such as hypermarkets expanded rapidly at the expense of traditional independent outlets, internet retailing and direct selling registered strong growth, and there were rapid changes in shopper purchasing habits for example, public \& private chain stores in Iran [1].

Euro monitor International's Retailing in Iran report offers insight into key trends and developments driving the industry. The report examines all retail channels to provide sector insight. Channels include hypermarkets, supermarkets, discounters, convenience stores, mixed retailers, health and beauty retailers, clothing and footwear retailers, furniture and furnishing stores, DIY and hardware stores, durable goods retailers, leisure and personal goods retailers [2].

There are profiles of leading retailers, with analysis of their performance and the challenges they face [3]. Euro monitor International has over 40 years' experience of publishing market research reports, business reference books and online information systems. With offices in London, Chicago, Singapore, Shanghai, Vilnius, Dubai, Cape Town, Santiago, Sydney, Tokyo and Bangalore and a network of over 800 analysts worldwide, Euro monitor International has a unique capability to develop reliable information resources to help drive informed strategic planning [4]. A position is the profile that companies strive to attain on a market and in the mind of the consumers. The position distinguishes a company from its competitors. A company's position must be evident and have a special place in the consumer's mind. The position indicates companies' benefits to the consumers [5]. They should aim at segments where they can offer the most and then position themselves and their products, so that the consumers know the advantages [6].

Sengupta (1997) [7] advances four components of positioning, which are product class, consumer segmentation, consumer perception and brand benefits. The product class denotes the set of products and brands which are perceived as substitute to satisfy some specific needs, it helps to identify the practical space in the mind of the consumer to occupy and the brands that are occupying such space presently. The particular brand that is occupying such space must be a close substitute of the intending brand for it to fit into the space thus knowing the space gives the picture of the structure of the market. Positioning is a marketing concept that outlines what a business should do to market its product or service to its customers. In positioning, the marketing department creates an image for the product based on its intended audience. This is created through the use of promotion, price, place and product (Lynn, 2019) [8].

With the interdependent and competitive markets, and with exigent consum- 
ers, most companies should decide how they can guide effectively this changing space (Lhotáková \& Olšanová, 2013) [9] in order to reach profitability. In the marketing strategy level, other components of marketing mix are based on the positioning and market segmentation. According to Brooks bank (1994) [10] selecting correct positioning strategy is not easy. Planning positioning strategy is a difficult and time-consuming task.

Retailers strongly needs the results of positioning analysis in order to formulate the most appropriate marketing and success strategies in the competitive space. Managers should review the applications of their marketing strategies. They should pay attention to the characteristics that customers use to distinguish the bran of retail stores and study the position of retail stores and their competitors. The purpose of this research was to determine the condition of positioning components in the retail market of Iran market (by emphasis on four retail stores including two public retail stores and two private retail stores.

\section{Literature Review}

In Amirshahi and Fayazaiazad [11] study for identifying the position and competitive condition of banks, two Melli (public) and Parsian (private) banks were selected to be evaluated from the customers' view. It was also tried to draw the position of these brands by using perceptual map technique. The study of Salehnia (2010) [12] considered the strategic positioning as a tool for identifying the sources of competitive advantage and positioning of brands in banking sector. Bayat (2011) [13], in the study titled "comparative study of international audiovisual devices' brand position in the market of Iran from the viewpoint of customers in Tehran city by using perceptual map technique", compared the competitive position of audiovisual devices' brand in the market of Iran. Rajabi (2011) [14] studied the necessity of brand positioning, especially in the studied industry (soft drink industry) by inspiring from the proposed position model of Aaker (2000) [15] they emphasized on four factors of product, brand owners 9 companies), brand personality and brand symbol as the effective factors on brand positioning. Adibfar (2011) [16] in a study titled "evaluating the effectiveness of positioning strategies from customers' viewpoint in the carpet industry (case study: Setareyekavir Yazd Company)", admits that positioning is a basic category in the marketing. Pakandish (2015) [17] in a study titled "explaining the effective factors on the strategic positioning: case study of Saderat Bank" presented a framework for evaluating strategic positioning. Mohammadi (2016) [18] in a study titled "bank brand positioning and drawing perceptual map of competitors from the customers' view (case study: MehrEghtesade bank in Qazvin province)", examined the position of this bank in relation with service quality model by using perceptual map from customers' view in comparing Mellat and Shahr banks in Qazvin. Nazari and Qavami (2017) [19] Proposed the model of brand validity effect on the brand alliance strategy in order to promote the position of brand strategic position. Chain stores national association provided a 
report in 2018 about the retail industry of Georgia that the summary of this market was presented based on the positioning indicators Union of Chains (2018) [20]. Schellhase et al. (2000) [21] published a research in industrial and commercial marketing journal and divided retailers' satisfaction dimensions into two instrumental aspects (different marketing mix elements) and Organization of the Interface between the manufacturer and the retailer. In a study titled "identifying target consumer in positioning process" Lhotakova and Klosova (2009) [22] stated that the development of a positioning strategy is relied on understanding the consumers, competitor and business strategies. In order to be effective, brand positioning should distinguish the brand from the competitors' brand and show that what an organization can do by passing the time. Finally, customers will realize the brand value. Hem and Teslo [23] in "brand positioning strategies" studied the common and constructive profitable distinction based on the secondary impressions as a part of brand positioning. Researchers obtained widespread results in brand positioning but the distinction based on the secondary impressions and the differences between common profitable and constructive distinction are less considered. Constructive profitable distinction related to the advantages which are directly related to the product performance while common profitable distinction associates with indirect advantages which expand communication in the consumption.

Akpoymare et al. (2013) [24] argued that product positioning is an important part of marketing because companies begin to identify the importance of controlling their image. This is a way for influencing the purchase decisions, customer perception and evaluating sale targets.

\section{Method}

This research was mixed methods (qualitative \& qualitative). Mixed methods research is a methodology for conducting research that involves collecting, analyzing and integrating quantitative (e.g., experiments, surveys) and qualitative (e.g., focus groups, interviews) research Tariq and et al. (2013) [25].

This analysis started by repeated studies between interview dataset. After determining significant propositions related to research subject, they were coded. Data of each study converted to them based on open coding. Main categories identified in this step. Based on axial coding, categories reduce to themes and axial themes identified in each study. Finally, selective coding was done.

First type: open coding: it is a process in which data are as separate meaningful units and can be used at the beginning of the study. The main goal of open coding is conceptualization and data labeling. In data analysis and code search, open coding is possible.

Second type: axial coding: it relies on determining a phenomenon by considering the conditions which lead to its development. These conditions include a context in which the category is located, action/interaction strategies which control the category, and the consequences of these strategies. Generally, axial cod- 
ing is connecting subcategories to a category. It is a complicated set of inductive and deductive reasoning which requires different steps. Axial coding, like open coding, is done through comparisons and questions. In axial coding, using these methods is concentrated and moves toward discovering the relations and connecting the categories to each other in a biased paradigm.

Third type: selective coding.

It relates to the selection of a category for central and related category.

In this research, data gathered through deep interviews with customers of selected private stores (O1 and J2) and public stores (R3 and S4).

Statistical population of the research includes all customers of selected private stores (O1 andJ2) and public stores (R3 and S4) in Tehran city. These customers were selected by following conditions for participation in the interview:

- Customers who had at least purchased continuously for one year from these four stores.

- Customers who are interested in interview.

- Data gathering based on view points of customers.

Private stores (O1 and J2) and public stores (R3 and S4) have 26, 31, 109 and 110 branches in Tehran, respectively.

This research used nonprobability sampling method (where there is no random method in selecting sample) and simple sampling (simple or convenient sampling). Simple sampling is a method in which available individuals and units are sampled for the ease of work during the study. Therefore, the researcher has referred to the four selected stores and interviewed with the qualified customers. Finally, 71 structured interviews were provided.

Research time scope was 2018. The place of sampling was selected branches of four stores located in Tehran city.

Since the nature of this research is qualitative, the researcher needs qualitative data to answer research question; therefore, interview was used in this research.

Researcher acted to design research questions by considering the goals and questions of research. Of course, in order to determine the validity of above questions, these questions were provided for supervisors and advisors as well as two academic experts and they confirmed it.

Since the methodology of this research is qualitative, data analysis was done by using coding in MAXQDA software. Some quantitative data were analyzed by using SPSS. V16 software.

\section{Finding}

For formulating the research theoretical model, by using academic sources, the papers, master and PH.D thesis focusing on positioning of retail stores were considered in this section. In this regard, 16 domestic and 19 foreign studies were used as valid academic sources. Among 35 studies, only 25 studies were considered to provide benchmark table. According to the studies, 28 factors were identified which are shown by the order of importance in Table 1. According to Table 1 about the frequency of obtained factors, it can be induced 
Table 1. Frequency of obtained factors in benchmark table.

\begin{tabular}{|c|c|c|c|c|c|c|c|}
\hline $\begin{array}{l}\text { Identification } \\
\text { factor }\end{array}$ & Frequency & $\begin{array}{l}\text { Identification } \\
\text { factor }\end{array}$ & Frequency & $\begin{array}{l}\text { Identification } \\
\text { factor }\end{array}$ & Frequency & $\begin{array}{l}\text { Identification } \\
\text { factor }\end{array}$ & Frequency \\
\hline 1) Price of products & 12 & 8) Number of branches & 2 & 15) Store' shelf & 1 & $\begin{array}{l}\text { 22) Shelf label with } \\
\text { stores' mark }\end{array}$ & 1 \\
\hline $\begin{array}{l}\text { 2) Quality of } \\
\text { products }\end{array}$ & 11 & 9) Arrangement & 2 & 16) Shelf s material type & 1 & $\begin{array}{l}\text { 23) Same colored } \\
\text { personnel uniform }\end{array}$ & 1 \\
\hline 3) Brand validity & 8 & 10) Parking & 2 & $\begin{array}{l}\text { 17) Separated entrance \& } \\
\text { exit }\end{array}$ & 1 & $\begin{array}{l}\text { 24) Number of } \\
\text { personnel in store }\end{array}$ & 1 \\
\hline 4) Product diversity & 5 & 11) Work hours & 1 & 18) Varrying vehicle & 1 & 25) ATM in store & 1 \\
\hline 5) Location of store & 4 & 12) Store area & 1 & 19) Coffeshop in store & 1 & 26) Loyalty card & 1 \\
\hline 6) Advertisement & 4 & 13) Number of shelves & 1 & 20) Recycyle bin in store & 1 & 27) Color of shelves & 1 \\
\hline $\begin{array}{l}\text { 7) Sales force } \\
\text { behavior }\end{array}$ & 3 & $\begin{array}{l}\text { 14) Commodities in } \\
\text { the shelves }\end{array}$ & 1 & $\begin{array}{l}\text { 21) Installing informa- } \\
\text { tion of store }\end{array}$ & 1 & 28) Atmosphere of store & 1 \\
\hline
\end{tabular}

that following cases are the most effective factors on positioning retail stores:

In order to formulate the positioning framework of Iranian retail stores, four stores were considered such that stores $\mathrm{O} 1$ and stores $\mathrm{J} 2$ were representative of private stores and stores $\mathrm{R} 3$ and stores $\mathrm{S} 4$ were public stores. In this regard, 71 interviews were done with the customers of aforementioned stores (predetermined questions).

Demographic characteristics of participants were such that approximately $48 \%$ of participants had B.A. About $71 \%$ of participants were lower than 30 years old. The contribution of participants of each store was: above $22 \%$ from store R3, above $22 \%$ from store S4, above $25 \%$ from store O1 and above $30 \%$ from store J2. Finally, it was determined that purchase history of $26 / 8 \%$ of participants was more than 6 years (Table 2).

During interview, some questions were asked from participants about the effective factors of retail stores' positioning. The results of data analysis identified 448 codes from structured interviews. Then, 448 initial codes were converted to 33 common codes including: as follows:

\begin{tabular}{lll}
\hline 1-Elevator & 12-Diversity of products and & 23-Area of store \\
2-Informing & brands & 24-Rest space \\
3-Suitable personnel behavior & 13-Atmosphere of the store & 25-W.C \\
4-Parking of store & 14-Suitable product & 26-Separate entrance \\
5-Accountability of personnel & arrangement & 27-Carts \\
6-Advertising & 15-Suggestions box & 28-ATM in store \\
7-Discount of products & 16-Play ground for children & 29-Coffeshop and restaurant \\
8-Number of branches & 17-Lottery and prize & in store \\
9-Number of cashiers & 18-Proper product price & 30-Appearance of personnel; \\
10-Number of counters & 19-Customers loyalty card & 31-ATM in store \\
11-Cleanness of the store & 20-Quality of store's & 32-Coffeeshop and restaurant \\
& air-conditioning & in store \\
& 21-Product quality & 33-Appearance of personnel \\
& 22-Proper product labeling & \\
\hline
\end{tabular}


Table 2. Demographic characteristics of participants' in 2018.

\begin{tabular}{|c|c|c|}
\hline Education level & $\mathbf{N}$ & $\%$ \\
\hline Diploma and associate degree & 14 & 19.7 \\
\hline Assistant & 8 & 11.3 \\
\hline BA & 26 & 36.6 \\
\hline MA & 19 & 26.8 \\
\hline Ph.D & 4 & 5.6 \\
\hline Total & 71 & 100.0 \\
\hline Age of participants & $\mathbf{N}$ & $\%$ \\
\hline$<30$ years & 12 & 16.9 \\
\hline $31-40$ years & 32 & 45.1 \\
\hline $41-50$ years & 17 & 23.9 \\
\hline $51-61$ years & 5 & 7.0 \\
\hline$>60$ years & 5 & 7.0 \\
\hline Total & 71 & 100.0 \\
\hline Marital status of participants & $\mathbf{N}$ & $\%$ \\
\hline Married & 44 & 62.0 \\
\hline Single & 27 & 38.0 \\
\hline Total & 71 & 100.0 \\
\hline The gender of the participants & $\mathbf{N}$ & $\%$ \\
\hline Man & 44 & 62.0 \\
\hline Female & 27 & 38.0 \\
\hline Total & 71 & 100.0 \\
\hline Store's name & $\mathbf{N}$ & $\%$ \\
\hline $\mathrm{O} 1$ (private stores) & 16 & 22.5 \\
\hline J2 (private stores) & 16 & 22.5 \\
\hline R1 (public stores) & 18 & 25.4 \\
\hline S2 (public stores) & 21 & 29.6 \\
\hline Total & 71 & 100.0 \\
\hline Participation Purchase History & $\mathbf{N}$ & $\%$ \\
\hline$<1$ year & 14 & 19.7 \\
\hline $1-2$ years & 14 & 19.7 \\
\hline $3-4$ years & 14 & 19.7 \\
\hline $5-6$ years & 10 & 14.1 \\
\hline$>6$ years & 19 & 26.8 \\
\hline Total & 71 & 100.0 \\
\hline
\end{tabular}

Finally, three axes (product, personnel and store) were considered for $33 \mathrm{ex}$ tracted codes. According to the frequency of obtained codes, the importance of these codes can be ranked. Generally, from among three obtained variables, commodity (203), store (198) and personnel (47) has the highest importance for Iran's retail store positioning, respectively. On the other hand, the importance of 
each component' variable is as following:

1) Commodity

- Commodity attraction: diversity of commodities and brands; quality of commodities;

- Commodity cost: suitable commodity cost; discounts;

- Providing commodity: proper arrangement of commodities; proper labeling

2) Store

- Store facilities: parking, playground for children, coffee shop and restaurant, elevator, W.C, ATM, rest space;

- Internal space of store: cleanness of store; area; space aesthetics, air-conditioning quality;

- External space of store: easy access; number of branches, separated exit;

- Store equipment: carts; cashiers; number of counters; suggestion box;

- Store promotions: customers' loyalty cards; lottery and prize; work hours, communication; advertising;

3) Personnel

- Personnel behavior component: proper behavior of personnel; personnel accountability;

- Appearance of personnel: physical appearance of personnel;

On the other hand, during interviews, researcher asked about the weaknesses of each four stores Data of this sector include cases in which the study customers have stated the weaknesses of each four stores. In this part, 183 codes extracted from 71 structured interviews. Then, these 183 initial codes converted to 30 common codes including: as follows:

\begin{tabular}{lll}
\hline 1-The possibility of returning & 11-Lack of proper advertising & 21-Lack of order in the store \\
commodities; & 12-Non-clean store & 22-Lack of equipment in \\
2-Unproper behavior of & 13-Lack of brands' diversity & store; \\
personnel; & 14-Lack of diversity of & 23-Lack of parking; \\
3-Undesidred odor in the & products; & 24-Lack of promotion and \\
store; & 15-Lack of discount & lottery; \\
4-Weak answering & attractions; & 25-Lack of rest place; \\
5-Changing prices & 16-Lack of store attraction; & 26-Lack of mobile charging \\
6-Atmosphere of store & 17-Lack of easy access; & place; \\
7-Unproper arrangement of & 18-Lack of proper decoration; & 27-Unproper price; \\
commodities; & 19-Lack of internet; & 28-Few branches; \\
8-Inappropriate working & 20-Ubsuitable carts; & 29-Unproper commodity \\
hours; & & quality \\
9-Few number of cashiers & & 30-Low area of store; \\
10-Unproper communication & & \\
\hline
\end{tabular}

Finally, three axes (commodity, personnel and store) extracted for the previous code were considered. Generally, among three obtained variables, commodity (96), store (66) and personnel (21) have the highest importance for Iran's retail stores' positioning, respectively. The importance of each variable is as follows:

1) Commodity: 
- commodity attraction: lack of commodities' diversity; lack of brands' diversity; unsuitable quality of commodity;

- commodity price: unsuitable price of commodities; lack of attractive discounts; changing prices;

- providing commodity: unsuitable arrangement of commodities; lack of proper decoration;

2) Store

- facilities of store: lack of recreational facilities; lack of parking; lack of rest place;

- internal space of store: low area store; unclean store; bad odor in store; store atmosphere; lack of store attraction; lack of order in store;

- external space of store: lack of easy access; few branches; separate exit for store;

- store equipment: few cashier; unsuitable carts; lack of mobile charging place;

- store advancements: lack of suitable information; lack of internet sale; lack of promotion and lottery; possibility of returning commodities; unsuitable work hours; lack of suitable advertising;

3) Personnel

- personnel behavior: week accountability; unsuitable behavior of personnel;

- Finally, regarding the obtained results of previous research, retail store positioning framework of Iran was formulated which is shown in Figure 1.

\section{Data Analysis}

Analyzing data of first interview question.

In this section, it was asked from participants that what the position of store in your mind is. Please think a moment about the store. Where is the position of store? (Select a number from 1 to 10). Data were analyzed.

\begin{tabular}{|c|}
\hline $\begin{array}{l}\text { Store } \\
\text {-store facilities: parking, playground for children; elevator, W.C; ATM; rest place } \\
\text {-store equipment: carts; number of cashiers; number of counters; suggestion box; mobile } \\
\text { charging place; } \\
\text {-internal store space: cleanness; area of store; atmosphere; space beauty; air-conditioning quality } \\
\text { of space; } \\
\text {-external space of store: easy access; number of branches; separate exit } \\
\text {-store advancements: customer loyalty card, lottery; work hours; informing, internet sale; } \\
\text { advertising }\end{array}$ \\
\hline $\begin{array}{l}\text { Iran's retail store } \\
\text { positioning }\end{array}$ \\
\hline $\begin{array}{l}\text { Commodity } \\
\text {-commodity attraction: commodity diversity; brand diversity; commodity quality } \\
\text {-commodity cost: suitable price; attractive discount } \\
\text {-providing commodity: proper arrangement of commodity; suitable labeling; proper } \\
\text { decoration; } \\
\text { Personnel } \\
\text {-personnel behavior: personnel suitable behavior' personnel accountability } \\
\text {-appearance of personnel: personnel physical condition }\end{array}$ \\
\hline
\end{tabular}

Figure 1. Iran's retail store positioning model. 
Contingency table was used to analyze the results. A contingency table is a tool in which you can see the effect of a qualitative variable (nominal or ordinal) on another qualitative variable. Another goal of the contingency table is finding the relationship between two variables. In contingency variable, many correlation tests are available which determine whether the relationship between variables is significant? One of the related tests is Chi-square test. Therefore, when data are nominal, the contingency table is a suitable method for the study of relationship between two variables. In this method, each variable is classified into two or more several classes and the number of frequencies related to each class of a variable place in the table. Through these classifications, we can specify the relationships between variables. The contingency table is typically forms as a two-dimensional table to study the presence or absence of the relationship between variables. Despite the widespread application of contingency table in the initial analysis of relationships between variables. This is not a strong technique, because it cannot determine the relationship between variables. For this reason, for more complicated analyses, especially when data is ordinal, interval or relative, other techniques are preferably used (Kalantari, 2012) [26].

Results of data analysis in answering the positioning of four stores in Table 3 show that:

- in position 2, J2 stores have the highest importance;

- in position 3, J2 and S4 have the highest importance;

- in position 4, J2, R3 and S4 stores have the highest importance;

- in position 5, S4 stores position have the highest importance;

- in position 6, O1 stores have the highest importance;

- $\quad$ in position 7, J2 stores have the highest importance;

- In position 8, O1 stores have the highest importance;

- In position 9, R3 stores have the highest importance;

- In position 10, R3 and S4 stores have the highest importance.

Table 3. Contingency table of store positioning in four stores.

\begin{tabular}{|c|c|c|c|c|c|c|}
\hline \multirow{2}{*}{\multicolumn{2}{|c|}{ Position }} & \multicolumn{4}{|c|}{ Store } & \multirow{2}{*}{ Total } \\
\hline & & O1 private & J2 private & R3 public & S4 public & \\
\hline \multirow{10}{*}{$\begin{array}{c}\text { Store } \\
\text { position }\end{array}$} & Position 1 & 0 & 0 & 0 & 0 & 0 \\
\hline & Position 2 & 0 & 1 & 0 & 0 & 1 \\
\hline & Position 3 & 0 & 1 & 0 & 1 & 2 \\
\hline & Position 4 & 0 & 2 & 2 & 2 & 6 \\
\hline & Position 5 & 3 & 1 & 1 & 8 & 13 \\
\hline & Position 6 & 4 & 3 & 2 & 3 & 12 \\
\hline & Position 7 & 2 & 4 & 1 & 1 & 8 \\
\hline & Position 8 & 4 & 1 & 5 & 4 & 14 \\
\hline & Position 9 & 2 & 2 & 5 & 0 & 9 \\
\hline & Position 10 & 1 & 1 & 2 & 2 & 6 \\
\hline \multicolumn{2}{|c|}{ Total } & 16 & 16 & 18 & 21 & 71 \\
\hline
\end{tabular}


Therefore, regarding the obtained scores, we can conclude that S4 (21 scores), R3 (18 scores), O1 and J2 (16 scores) have the best position in the mind of customers. In other words, positioning of public stores is more successful than private stores (Table 3 ).

\section{Discussion and Conclusion}

In order to determine the positioning framework of Iran's retail stores, four stores were considered such that $\mathrm{O} 1$ and $\mathrm{J} 2$ stores were representatives of private stores, and R3 and S4store were representatives of public retail stores. In this regard, 71 interviews were carries out in structured form (predetermined questions). It is worthy to mention that three questions were asked from participants (two open questions and one closed question) as following:

1) Generally, what is the position of this store in your mind? Think a moment to this store. What is the position of this store? (Select a number from 1 to 10).

2) What factors were effective on you to select this store for purchase?

3) What are the weaknesses of this store compared to other stores?

As observed, question 1 is in open form and questions 2 and 3 are in open forms. In fact, questions 2 and 3 were used to formulate a positioning framework for retail stores of Iran, and question one was for evaluating the positioning condition of four stores. Question 2 had positive aspect and question 3 had negative aspect. The reasoning of researcher was than by imposing positive and negative aspects of positioning, a more accurate model can be obtained.

Regarding what has said in the conclusion section, we will provide some applied suggestion in order to enhance the position of Iran's retail stores in Iran.

- The obtained model indicates the importance of commodity for the customers. Therefore, it is necessary that retail stores in Iran focus more on this factor by increasing the attraction of commodity for customer (by commodity diversity, brand diversity and commodity quality), price of commodity (suitable prices and attractive discounts) and providing commodity (suitable arrangement of commodity, suitable labeling and suitable decoration). Of course, commodity is identified as the most important factor in positioning of retail stores which is hesitating and emphasizes the importance of focus on commodity.

- The second effective factor on the position of retail store is the store itself which the focus should be on store facilities such as parking, playground for children, coffee shop and restaurant, elevator, W.C, ATM and rest place.

- Retail stores should pay attention to the internal space of store. In this regard, cases like store cleanness, area of store, atmosphere, space beauty and quality of air-conditioning.

- External space of store can be promoted by cases like easy access, number of branches, and separate exit.

- Retail stores should inspect the equipment of store. In this regard, focus in on cases like carts, number of cashiers, and number of counters, suggestion box 
and mobile charging place.

- Store advancement or promotions are important factors. In this regard, the focus in on the cases like customers' loyalty cards, lottery and promotion, work hours of store, informing, internet dale and advertising.

- The third important factor in positioning retail store was personnel. In this regard, relevant authorities should emphasize the behavior of personnel with customer needs patience, mastery in functions, advantages, price and etc.

\section{Conclusion}

Therefore, regarding the obtained scores, we can conclude that S4 (21 scores), R3 (18 scores), O 1 and J2 (16 scores) have the best position in the mind of customers. In other words, positioning of public stores is more successful than private stores.

\section{Applied Suggestion}

In this research, the factors influencing the positioning of retail stores were commodity, stores and personnel respectively. In this regard, what the mind of the scholar is engaged in is whether this sequence of sequences is rooted in the cultural issues of the country or originates from the taste and taste of the customers. Therefore, the study of the root of this ranking as a qualitative research in the Ph.D. degree is recommended to shoppers in the area of retail stores.

\section{Acknowledgements}

The first author gratefully acknowledges that the present research is founded by the second and the third author research in my university.

\section{Conflicts of Interest}

The authors declare no conflicts of interest regarding the publication of this paper.

\section{References}

[1] Pantano, E. and Viassone, M. (2015) Engaging Consumers on New Integrated Multichannel Retail Settings: Challenges for Retailers. Journal of Retailing and Consumer Services, 25, 106-114. https://doi.org/10.1016/j.jretconser.2015.04.003

[2] http://http:www.marketreportsonsaudiarabia.com

[3] https://shandaconsult.com/chain-stores-increasing-iran

[4] Euro monitor, I. (2014) Retailing in Iran. International Euro Monitor, London.

[5] Dibb, S., Simkin, L., Pride, W. and Ferrell, O.C. (2001) Marketing Concepts and Strategies. Houghton Mifflin, Boston.

[6] Kotler, P., Armstrong, G., Saunders, J. and Wong, V. (1999) Principles of Marketing. Prentice-Hall, Upper Saddle River, NJ.

[7] Sengupta, S. (1997) Brand Positioning. McGraw Hill, New Delhi.

[8] Lynn, L. (2019) What Is Positioning in a Marketing Plan. What Is Positioning in a Marketing Plan. Small Business-Chron. https://smallbusiness.chron.com

[9] Lhotáková, M. and Olšanová, K. (2013) The Role of Positioning in Strategic Brand 
Management-Case of Home Appliance Market. Global Journal of Commerce and Management Perspective, 2, 71-81.

[10] Brooksbank, R. (1994) The Anatomy of Marketing Positioning Strategy. Marketing Intelligence \& Planning, 12, 10-14. https://doi.org/10.1108/02634509410060695

[11] Mirahmad, A.S. and Ali, F.A. (2010) Investigating the Position of Banks' Brand from the Perspective of True Customers of Tehran City Using the Perceptual Mapping Technology (Case Study: Brand of National and Parsian Banks). Quarterly Journal of Business Management, 2, 1-27.

[12] Monireh, S.N. (2010) Strategic Positioning and Identification of Access Resources for Sustainable Competitive Advantage (Case Study): Strategic Positioning of Commercial Names in the Banking Sector. 2nd International Financial Services Marketing Conference, Tehran, Iran, 19.

[13] Bayat, S. (2011) Comparative Study of the Position of International Brands of Active Audio and Video Equipment in the Iranian Market from the Viewpoint of Customers in Tehran Using Perceptual Mapping Technique. Master's Thesis, Tarbiat Modares University, Tehran.

[14] Rajabi, S. (2011) Factors Affecting Brand Positioning (Case Study: A Survey of the Drinking Industry in Tehran). Master's Thesis, Allameh Tabataba'i University, Tehran.

[15] Aaker, D. and Joachimsthalaer, E.A. (2000) The Brand Relationship Spectrum: The Key to the Brand Architecture Challenge. California Management Review, 42, 8-23. https://doi.org/10.1177/000812560004200401

[16] Adibfar, F. (2011) Evaluating the Effectiveness of Positioning Strategies from the Perspective of Customers in the Carpet Industry (Case Study: StearKavir Carpet Yazd). Master's Degree Program, Shahid Beheshti University, Tehran.

[17] Pakandish, H. (2015) Explaining the Factors Affecting Strategic Positioning Case Study: Bank Saderat Iran. Master's Thesis, Tehran University, Tehran.

[18] Mohammadi, H. (2017) Bridging the Brand of Banks and Drawing a Perceptual Map of Competitors from Customers' Point of View (Case Study of Mehr Economics Bank in Qazvin Province). Master's Degree, Higher Education Institution of Takestan, Qazvin, Iran.

[19] Nazari, R. and QavamiKomala, F. (2017) The Effect of Brand Credit on Brand Struggle Strategy to Promote Brand Strategic Position: A Case Study; Sepahan Club of Isfahan. Applied Research in Sport Management, 6, 32.

[20] Union of Chains (2018) Reporting and Analyzing the Retail Industry of Georgia. http://www.etkfz.com/

[21] Schellhase, R., Hardock, P. and Ohlwein, M. (2000) Customer Satisfaction in Business-to-Business Marketing: The Case of Retail Organizations and Their Suppliers. Journal of Business and Industrial Marketing, 15, 106-121.

[22] Lhotáková, M. and Klosová, A. (2009) Identification of a Target Consumer in Process of Positioning: Theoretical and Practical Aspects. Acta Oeconomica Pragensia, 3, 3-24. https://doi.org/10.18267/j.aop.270

[23] Hem, A.F. and Teslo, P.C.S. (2012) Brand Positioning Strategies: An Experimental Test of Two Types of Benefit Differentiation. Master Thesis, NORGES HANDELSHØYSKOLE, Bergen, 17 December 2012.

[24] Akpoyomare, O.B., Adeosun, L.P.K. and Ganiyu, R.A. (2013) Approaches for Generating and Evaluating Product Positioning Strategy. International Journal of Business Administration, 4, 46-52. https://doi.org/10.5430/ijba.v4n1p46 
[25] Tariq, S. and Woodman, J. (2013) Using Mixed Methods in Health Research. JRSM Short Reports, 4. https://doi.org/10.1177/2042533313479197

[26] Kalantari, B. (2010) Herbert A. Simon on Making Decisions: Enduring Insights and Bounded Rationality. Journal of Management History, 16, 509-520.

https://doi.org/10.1108/17511341011073988 